Asian Journal of Economic Modelling

$\operatorname{ISSN}(e): \quad 2312-3656$

$\operatorname{ISSN}(p): \quad 2313-2884$

DOI: $10.184 .88 /$ journal.8.2020.84.227.240

Vol. 8, No. 4, 227-240.

(C) 2020 AESS Publications. All Rights Reserved.

URL: wrw.aessweb.com

check for
updates

\title{
CRUDE OIL PRICE, URBANIZATION AND ENVIRONMENTAL POLLUTION IN NIGERIA: EVIDENCE FROM ARDL APPROACH
}

\author{
Rabiu Maijama'a ${ }^{1+}$ \\ Kabiru Saidu Musa ${ }^{2}$
}

\author{
${ }^{\prime}$ Nigerian National Petroleum Corporation, NNPC Towers, Central \\ Business District, Garki, Abuja-Nigeria. \\ Email:Rabiumaijamaa19@gmail.com Tel:+2348033896237 \\ ${ }^{2}$ Department of Economics, Faculty of Social and Management Sciences, \\ Bauchi State University Gadau, Yuli Campus, Bauchi-Nigeria. \\ Email:Kabirusaidumusa@gmail.com Tel:+2348030915903
}

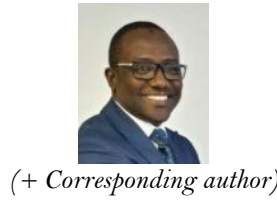

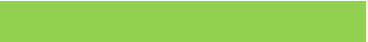

Article History

Received: 24 June 2020 Revised: 27 July 2020 Accepted: 18 August 2020 Published: 9 September 2020

\section{Keywords}

Crude oil price

Urbanization

Environmental pollution

ARDL approach

ADF

KPSS unit root tests.

JEL Classification: Q41; R23; Q53.

\section{ABSTRACT}

The impacts of crude oil price and urbanization on environmental pollution in Nigeria for the time frame of 1981 to 2016 is the main objective of this paper and the objective was achieved through the application of Augmented Dickey Fuller and Kwiatkowski Philip Schmidt Shin unit root tests together with Autoregressive Distributed Lag Model in the process of achieving stationarity and cointegration among the variables. The results obtained showed from ADF indicate that foreign direct investment and urbanization were stationary at level while environmental pollution and crude oil price at first difference. But KPSS result revealed that all the variables with the exception of urbanization were stationary at level and the bound test result revealed that all the variables are cointegrated. The long-run and the short-run findings indicate that foreign direct investment and crude oil price have significant negative sign with environmental pollution for the periods under study and this shows that these variables are helps in ensuring clean environment and maintain the quality of the environment. But urbanization results from the long-run and the short-run models shows that it has significant positive sign with environmental pollution and this signifies that urbanization is among the drivers of environmental pollution in the country. We recommend that for the country to maintain good environmental quality the country must limit the process of urbanization to best level in order to reduce the associated environmental impacts and to maintain balance were the quality of the environment is not harm by the increasing urbanization.

Contribution/ Originality: This study contributes to the existing literatures by providing evidence that rise in crude oil price helps in reducing the level of environmental pollution and urbanization is accountable for the increase in the level of environmental pollution in Nigeria.

\section{INTRODUCTION}

From the 1960s, as universal environmental problems started to be exposed and debated, there was an emphasis mainly on the absolute numbers of individuals and their possible negative influence on the earth (Newman, 2006). Growing economic activities and population have greater part to play in the equality of the environment and the country's $\mathrm{CO}_{2}$ emissions condition as the knowledge of urbanization causing the emissions of $\mathrm{CO}_{2}$ can be vindicated through numerous ways and one of the clear ways is through consuming energy by the increasing population in the urban areas. Nation's concentration on urbanization with new and advancement of 
infrastructural development in the ancient and new towns implies that large amount of those happenings will be carried out with the help of actions that necessitate some level of energy consumption. The involvement of substantial infrastructure in the processes for a long-run period and the constant utilization of the nation's endowed natural resources in the system as fuel, $\mathrm{CO}_{2}$ emissions and waste which are the final outcomes of the process contaminated the air, soil fertility and portable water which ultimately influence the equality of the environment negatively (Mahmood et al., 2020).

Nigeria, in Africa and the world at large, is well-known for its endowed natural resources which include oil and gas. With the presence of the endowed natural resources, the country's exports have augmented sufficiently higher in order to ensure the realization of sufficient volume of earnings from foreign exchange and stability in economic growth (Maalel \& Mahmood, 2018; Musa, Maijama'a, Shaibu, \& Muhammad, 2019). At this point, the contribution of crude oil price determination of oil profits and country's level of income is considered significant. During the period of rising crude oil prices and urbanization, environmental pollution would be regarded as one of the greatest disturbing issue across all the crude oil exporting nations together with the aforementioned augmented growth of the economy because the nation's oil sector is likely to increase the level of environmental pollution as more attention continued on the production of oil with increasing crude oil price and significantly causing increase earnings from oil crude oil exports. But production of crude oil alone might not help in decreasing the level of environmental pollution even with the adoption of clean technologies and reducing over reliance on crude oil will be the long-lasting solution to this disturbing circumstance (Mahmood et al., 2020). Therefore, careful investigation needs to be done in order to capture the existing influence and to guide the bundle of strategies to substantiate the nation's clean environment as the growing oil sector of the nation may rises the level of environmental pollution and also destroy equality of the environment through $\mathrm{CO}_{2}$ emissions (Mahmood et al., 2020).

the part played by urbanization is negative in environmental pollution and the reason for that arises from the large amount of energy consumption for the achievement of better standard of living in the urban cities. Equally, urbanization may also have suitable influence on the equality of the environment if the population are appropriately guided and educated with the facts about the environment (Mahmood et al., 2020). In the case of South Asian nations, Ahmad, Iqbal, and Mahmood (2013) shows that population and industrial activities have significant positive influence on the environmental pollution of the region and this implies that industrial activities and population are the major contributing factors to environmental pollution in the South Asian nations. In the case of Saudi Arabia, Mahmood et al. (2020) posit that country's rapidly growing population and subsequently expanding urbanization may be counted as unsafe for the environment because of substantial usage of low-priced fossil fuel energy in the Kingdom and the main determinants of the country's pollution which are industrial and transportation sectors are encouraged by the increasing growth of the nation. Also, in the case of Egypt, the investigations (Mahmood, Furqan, Alkhateeb, \& Fawaz, 2019a) on the possible sources of environmental pollution in the country for the period of 1990 to 2014 revealed that level of income has quadratic result while foreign direct investment and trade openness have insignificant negative outcome on environmental pollution.

In general, crude oil exporting countries are likely to be victim of environmental issues which is due to increasing oil exploration, low local energy prices and increasing local oil consumption. Therefore, it is important to identified the significant determinants of environmental pollution in order to design a measure for the control of the environmental issues. Even though many literatures exist with the influence of financial market and trade openness on environmental pollution in Nigeria and other oil exporting countries (Al-mulali \& Ozturk, 2015; Farhani \& Ozturk, 2015; Mahmood \& Alkhateeb, 2017; Maji, 2015; Zamil, Furqan, \& Mahmood, 2019). Nevertheless, inspecting the impact of urbanization and oil price on the environmental pollution is completely absent in the environmental literature of Nigeria.

It is important to note that any theoretical assumption regarding the existence of negative or positive influence of the determinants of environmental pollution is not effective in the absence of thorough research as it is 
imperative to witness the extent and the degree of the correlation between the environmental pollution and its determinants. Therefore, the studying the effects of urbanization and oil sector on the emissions of pollution may be right for an important input in the case of Nigerian literature. This current investigation is also extremely motivated to discover the significant impacts of urbanization and oil price on the environmental pollution in Nigeria using the sample periods spanning 1981-2016 and recommend an effective strategy to overcome the environmental issues.

\section{LITERATURE REVIEW}

Firstly, we will be concerned with seeing the impacts of crude oil price on the nations' economy and environment. The few among these studies that connect these variables includes, Olusanya (2012) inspects the long run correlation between energy consumption and the economic growth in Nigeria over 1985 to 2010 period. study analyzed the data using ordinary least square method and the outcomes indicate that electricity and petroleum have significant positive impact on economic growth whereas coal and gas revealed a significant negative influence on economic growth. Nevertheless, the study concludes that economic growth in Nigeria is strongly determined. By rise in energy consumption in Nigeria for the period under study by merging crude oil price in the investigation of the possible causal association among economic growth, $\mathrm{CO}_{2}$ emissions and energy consumption in the case of Saudi Arabian economy using method of variance decomposition, Alshehry and Belloumi (2015) discovered that rising level of energy consumption might not possibly create meaningful economic growth through economic activities but intensified the stage of country's $\mathrm{CO}_{2}$ emissions because of fundamental impact of oil revenue on economic activities in the oil endowed and dependent economy. Saboori, Al-Mulali, Bin Baba, and Mohammed (2016) discovered that quality of the environment intensified significantly with growing economic growth and oil consumption but significantly decline in relation to crude oil price in the long-run period. Though, no significant causal association was revealed among crude oil price, oil consumption and the quality of the environment, but significant causal association was reported running from crude oil price to oil consumption for only Algeria and United Arab Emirates. The investigation was done with the help of ADRL approach, Toda and Yamamoto modified Wald test for granger causality using data from 1977 to 2008 in order to proof the existence of EKC for 10 OPEC member nations. Acar (2017) recommends that dependency on crude oil contributes meaningfully to the problems of sustainability in crude oil abundant and dependent nations. It is, nevertheless, shocking that very limited number of the present researches have measured the connecting the impact of price of crude oil on the consumption of energy and $\mathrm{CO}_{2}$ emissions in oil endowed and abundant nations, where receipt from crude oil export is a serious means of fiscal spending that creates a lots of economic events. Using Ecuador as a case study, Nwani (2017) studied the connecting relationship among price of crude oil, $\mathrm{CO}_{2}$ emissions and energy consumption for period spanning 1971 to 2013 and include economic growth by means of income per capita. The study was possible with the help of ARDL and granger causality test and the outcome showed that high oil revenue generate economic situations that require additional consumption of energy which significantly resulted in $\mathrm{CO}_{2}$ emissions in the economy for the two periods. Also, unidirectional causality exists from crude oil price to energy consumption and economic growth, and from $\mathrm{CO}_{2}$ emissions to economic growth with bidirectional causality between energy consumption and $\mathrm{CO}_{2}$ emissions. In the case of G-7 member nations and applied method of historical decomposition, Balcilar, Ozdemir, Ozdemir, and Shahbaz (2018) investigates the existing relationship between energy consumption, economic growth and $\mathrm{CO}_{2}$ emissions and the outcome revealed that it is required that nations such as Italy, USA, Japan and Canada need to surrender those economic activities in order to lessen $\mathrm{CO}_{2}$ emissions by prohibiting the consumption of energy from non-renewable source while for Germany, US, Canada, Japan and UK the result indicate that environmental kuznet curve does not hold as the environmental quality is not affected by economic growth in UK and Germany. Agbanike et al. (2019) offers an understanding into sustainability issues in the case of Venezuela by discovering the causal interactions between crude oil price, consumption of energy and 
$\mathrm{CO}_{2}$ emissions using ADRL and causality test to analyze the data for the period 1971-2013. The outcome shows that rising crude oil price significant positive sign with energy consumption, expenditure on government consumption and consumption of energy create $\mathrm{CO}_{2}$ emissions, while $\mathrm{CO}_{2}$ emissions apply negative influence on crude oil dependent economic growth. Unidirectional causality between price of crude oil and energy consumption, energy consumption and $\mathrm{CO}_{2}$ emissions and $\mathrm{CO}_{2}$ emissions with economic growth. In realizing the influence of crude oil price and exchange rate on economic growth using a case of Nigeria, Musa et al. (2019) applied ARDL bound approach for cointegration to analyze the data for the period spanning 1982-2018. The outcomes of the influence revealed that crude oil price and exchange rate have significant positive sign with economic growth within the short-run and in the long-run periods. The empirical finding recommends that crude oil price and exchange rate have long-run and the short-run influence on economic growth. In another development and by means of ARDL bound approach to analyze the time series data for the period of 1983 to 2017, Musa., Maijama'a, Mohammed, and Adamu (2020) investigate the impact of crude oil price on exchange using Nigeria as a case study. The outcome of the investigation catch a significant negative sign of oil price on exchange rate within the long-run and the shortrun periods while economic growth and oil revenue possess significant positive sign with exchange rate for the two periods and they conclude that the influence of oil price on exchange rate is the dual one.

The second section of the literature review focus on the connection between urbanization and environmental pollution and the ones reviewed include Ohwo and Abotutu (2015) in their study revealed the evidences of environmental influence of urbanization in Nigeria. The associations between urbanization progression and the environment are indicated that the main mechanisms of the environment that include air, water and land are unfavorably distressed by the everyday anthropogenic actions of urban dwelling and in the course of exploiting the natural resource. The objective of certifying environmental sustainability is seriously endangered by urbanization and has generated numerous serious environmental problems and they have negative influences on man and other living organisms in the environment. Therefore, if the pressures modeled by urbanization in the country are not effectively accomplished, the size of the environment to uninterruptedly conform life may be endangered with terrible penalties on human life expectancy. Begum, Sohag, Abdullah, and Jaafar (2015) scrutinized the influence of population growth, economic growth and energy consumption on $\mathrm{CO}_{2}$ emissions. The outcome of the scrutinization revealed that $\mathrm{CO}_{2}$ emissions increase economic growth and that the increase in $\mathrm{CO} 2$ emissions was abnormal from 1980 to 2009 and the increased in economic growth was the same. The findings also indicate that economic growth and energy consumption have long run joints positive impacts on $\mathrm{CO}_{2}$ emissions. Kasman and Duman (2015) investigated the causal nexus among urbanization, energy consumption, economic growth carbon emissions and trade openness for a panel of EU countriesovertheperiod 1992-2010. They exerted panel causality tests, panel unit root test, and panel cointegration methodologies. According to their results, the evidence of Environmental Kuznets Curve hypothesis is supported. This proved that there is an inverted U-shaped correlation between environment pollution and economic growth for the selected countries. Khobai and Le Roux (2017) investigate the association between urbanization, energy consumption, $\mathrm{CO}_{2}$ emissions, trade openness and economic growth from 1971-2013 periods for South Africa as a case study. The data were examined using Johansen Juselius test for cointegration and Granger causality base on vector error correction model. After the discovery of the long run equilibrium relationship between the series, the existence of long run bidirectional causality running from energy use to economic growth was reported. Behera and Dash (2017) inspected the possible interrelationship among urbanization, foreign direct investment, energy consumption and $\mathrm{CO}_{2}$ emissions using sample of 17 nations from the South and Southeast Asian (SSEA) areas for over 1980-2012 periods. The outcome from the Pedroni cointegration indicates that $\mathrm{CO}_{2}$ emissions is significantly influence by energy consumption using fossil fuel and primary energy consumption. Ikporukpo (2018) studied the relationship between urbanization and environment using two cities in Nigeria, based on solid waste, sewage, water, air and noise pollutions, shows that, even though the influence has deteriorated over the years, it lingers to be significant. An additional thorough investigation of the 
condition in the two towns of Abuja and Yenagoa displays evidently the role that actual environmental management played in an improvement of the influence implying that the development-stage-dependent facilitator school of thought is the most important in the Nigerian experience. Isik, Dogru, and Turk (2018) investigates the interrelationship between energy consumption, urbanization, environmental pollution and economic growth using technique of heterogeneous panel analysis such as dynamic ordinary (DOLS) least squares, fully modified least squares (FMOLS) and granger causality test to analyzed the data. The outcomes indicate that there is an equilibrium long run association between $\mathrm{CO}_{2}$ emissions, GDP, structure of energy consumption and urbanization. in all the provincial panels, energy consumption and economic growth have influence on $\mathrm{CO}_{2}$ emissions but urbanization influence on $\mathrm{CO}_{2}$ emissions is only within the provinces of national and medium-developed. While in the provinces of China, Ahmad. et al. (2018) utilized ARDL approach to study the influence of energy consumption, economic growth and total population on $\mathrm{CO}_{2}$ emissions over 1971-2013 periods. Their outcome recognizes a connection between economic growth and $\mathrm{CO}_{2}$ emissions which confirms the existence of cointegration among the variables. Granger causality test result shows the presence of unidirectional causality among economic growth and $\mathrm{CO}_{2}$ emissions and lastly, outcome shows that energy consumption and economic growth are responsible for the increasing level of $\mathrm{CO}_{2}$ emissions in the country. have got great potential to encourage carbon productions in the long run. Mahmood et al. (2020) studied the impacts of urbanization, industrialization on $\mathrm{CO}_{2}$ emissions covering 1968-2014 periods in Saudi Arabia. By means of linear and nonlinear ARDL models, the results revealed that urbanization and industrialization have obstruct the environment with urbanization having flexible consequence while industrialization having rigid consequence on carbon dioxide emissions. The asymmetry is reported between industrialization and carbon dioxide emissions and the growing industrialization has greater environmental consequence than declining industrialization.

Therefore, from the reviewed literature it is obvious that study on the relationship between crude oil price and environmental pollution is lacking in the case of Nigeria and this study will contribute to the existence literature in this area by studying the impact of crude oil price and urbanization on environmental pollution using ARDL procedure for the period of 1981 to 2016.

\section{DATA, EMPIRICAL MODEL AND METHODOLOGY}

\subsection{Definition of Variables and Data Description}

This study employed yearly data for over 1981-2016 period. $\mathrm{CO}_{2}$ emissions which is proxy for environmental pollution are measured in country's total $\mathrm{CO}_{2}$ emissions metric tons. Urbanization is measured using urban population. Foreign direct investment is captured by Foreign direct investment, net inflows (\% of GDP). International crude oil price is measured in US dollars per barrel. Table 1 shows the definition and the sources of data for all the variables used in this paper, while the plots of the variables are illustrated in Figure 1.

Table-1. Variable measurements, data definition and sources

\begin{tabular}{l|l|l}
\hline Variables & Definition & Source \\
\hline $\mathrm{EV}_{\mathrm{t}}$ & $\mathrm{CO}_{2}$ emissions (metric tons) & $\begin{array}{l}\text { Fossil } \mathrm{CO}_{2} \text { and GHG emissions of all world } \\
\text { countries, 2019 report. }\end{array}$ \\
\hline $\mathrm{OP}_{\mathrm{t}}$ & Crude oil price (US\$ per barrel) & OPEC Statista, 2020 \\
\hline $\mathrm{UB}_{\mathrm{t}}$ & Urban population & World Development Indicators, World Bank \\
\hline $\mathrm{FI}_{\mathrm{t}}$ & $\begin{array}{l}\text { Foreign direct investment, net inflows } \\
\text { of GDP) }\end{array}$ & World Development Indicators, World Bank \\
\hline
\end{tabular}

Source: $\mathrm{CO}_{2}$ and GHG emissions countries reports 2019; OPEC (2020); WDI (2020). 


\subsection{Empirical Model and Estimation Method}

This study adapts and modified the model of Mahmood et al. (2020) in order to study the empirical connection among price of crude oil, urbanization and $\mathrm{CO}_{2}$ emissions in Nigeria were Foreign direct investment is used as control variables and the model can be finally written as:

$$
E V_{t}=f\left(O P_{t}, U B_{t}, F I_{t}\right)
$$

Where $\mathrm{EV}_{\mathrm{t}}$ is the environmental pollution at time $\mathrm{t}$; $\mathrm{OP}_{\mathrm{t}}$ is the crude oil price at time $\mathrm{t}$; $\mathrm{UB}_{\mathrm{t}}$ is the urbanization at time $\mathrm{t} ; \mathrm{FI}_{\mathrm{t}}$ is the foreign direct investment at time $\mathrm{t}$.

To decrease skewness in the time series data, the natural logarithmic linear specification offers healthier outcomes when related with functional form linear Equation and as such, following researchers such as Ahmed, Shahbaz, Qasim, and Long (2015); Maji (2015); Musa et al. (2019) we adapt and developed a logarithmic linear econometric model that consist of drift coefficient and the disturbance term, where the disturbance term is anticipated to be normally distributed with zero mean and constant variance. Therefore, the econometric association between our series is given in Equation 2.

$$
\ln E V_{t}=\phi_{0}+\phi_{1} \ln O P_{t}+\phi_{2} \ln U B_{t}+\phi_{3} F I_{t}+\zeta_{t}
$$

Here, $\ln$ represent the natural logarithmic sign; $\phi_{0}$ represent the constant parameter; $\phi_{1} \ldots . . . \phi_{4}$ stands for the coefficients of explanatory variables; $\mathrm{EV}_{\mathrm{t}}$ is the environmental pollution at time $\mathrm{t}$; $\mathrm{OP}_{\mathrm{t}}$ is the crude oil price; $\mathrm{UB}_{\mathrm{t}}$ is the urbanization; and $\zeta_{t}$ represent the error term.

offers unbiased values of the series along with valid test-statistics even when the independent series are endogenous (Pesaran, Shin, \& Smith, 2001). These statistical structures have made ARDL bounds method to longrun equilibrium relationship common between scholars in the present years (Ali, Abdullah, \& Azam, 2017; Imamoglu, 2019; Khraief, Shahbaz, Mallick, \& Loganathan, 2018; Mahalik, Babu, Loganathan, \& Shahbaz, 2017; Mahmood et al., 2020; Musa, Maijama’a, Mohammed, \& Usman, 2020; Musa et al., 2019; Rafindadi, 2016; Shahbaz, Hye, Tiwari, \& Leitão, 2013; Sulaiman \& Abdul-Rahim, 2018) among other researchers. The application of ARDL bounds method includes examining the existence of a long run equilibrium connection based on the logarithmic linear description in the equation by means of an unrestricted error correction model (UECM) structure that assimilates the dynamics short run together with the long run equilibrium without losing any long run evidence. The empirical construction of the ARDL bounds examination method to cointegration is specified in Equation 3.

$$
\begin{aligned}
\ln E V_{t}=\varphi_{0}+ & \varphi_{1} \ln E V_{t-j}+\varphi_{2} \ln O P_{t-j}+\varphi_{3} \ln U B_{t-j}+\varphi_{4} \ln F I_{t-j}+ \\
& \sum_{j=1}^{m 1} \Delta \beta_{1 j} \ln E V_{t-j}+\sum_{j=0}^{m 2} \Delta \beta_{2 j} \ln O P_{t-j}+\sum_{j=0}^{m 3} \Delta \beta_{3 j} \ln U B_{t-j}+ \\
& \sum_{j=0}^{m 4} \Delta \beta_{4 j} \ln F I_{t-j}+\zeta_{2 t}
\end{aligned}
$$

Where $\varphi_{1} \ldots \ldots \varphi_{5}$ stands for the long-run coefficients; $\beta_{1} \ldots \ldots \beta_{5}$ The null hypothesis of no cointegration among the series in Equation 3 is given as $\boldsymbol{H}_{\mathrm{O}}: \boldsymbol{\beta}_{1}=\boldsymbol{\beta}_{2}=\boldsymbol{\beta}_{3}=\boldsymbol{\beta}_{4}=\mathrm{O}$ is established compared to the alternate hypothesis which is given as $\boldsymbol{H}_{1}: \boldsymbol{\beta}_{1} \neq \boldsymbol{\beta}_{2} \neq \boldsymbol{\beta}_{3} \neq \boldsymbol{\beta}_{4} \neq 0$

The choice to accept or to reject the $\mathrm{H}_{0}$ which is the null hypothesis for no-cointegration or long run relationship between the series is on the basis of the following circumstances:

a. When the estimated F-statistics is larger than the lower and the upper critical bounds values, then is rejection of $\mathrm{H}_{0}$ occurred and the series are said to be cointegrated. 
b. When the estimated F-statistics is below the lower bound value, then $\mathrm{H}_{0}$ is not rejected and the series are not cointegrated.

c. But when the estimated F-statistics is in between the lower and upper critical bounds values then the result is said to be inconclusive (Pesaran et al., 2001).

Therefore, the long-run and short-run parameters of the series are assessed when the rejection of the null hypothesis that says no cointegration relationship takes place and subsequently establishment of the long-run relationship among the series. The formulation for the calculation of a dynamic short-run coefficients are based on the structure of error correction model (ECM) in Equation 4.

$$
\begin{aligned}
\ln E V_{t}=\varphi_{1}+ & \sum_{j=1}^{m 1} \Delta \beta_{1 j} \ln E V_{t-j}+\sum_{j=0}^{m 2} \Delta \beta_{2 j} \ln O P_{t-j}+\sum_{j=0}^{m 3} \Delta \beta_{3 j} \ln U B_{t-j}+ \\
& \sum_{j=0}^{m 4} \Delta \beta_{4 j} \ln F I_{t-j}+\chi E C T_{t-1}+\zeta_{3 t}
\end{aligned}
$$

The existence of dynamic short-run relationship in Equation 4 depends on $\chi$ being negative, less than one in value and significant and it also depicts the speed of adjustment back to equilibrium from disequilibrium position. After that, the calculated parameters of differenced series are considered as short-run elasticity values.

In corroborating Pesaran et al. (2001) the stability of long run and short run coefficients is scrutinized by the CUSUM (cumulative sum) and CUSUMSQ (cumulative sum of squares). The following appropriate reliability tests are engaged to evaluate the strength of the calculated Equations using normality test Jarque-Bera; serial correlation LM test based on Breusch-Godfrey; Functional form test using Ramsey RESET test and heteroskedasticity test based on Breusch-Pagan-Godfrey.

\section{EMPIRICAL RESULTS AND DISCUSSION FINDINGS}

This section of the empirical results graphical presentation of the connection between environmental pollution, crude oil price and urbanization in Nigeria all in Figure 1. The plots of foreign direct investments, environmental pollution and crude oil price shows fluctuation trends throughout the 1981-2016 periods whereas urbanization maintained a positive and increasing trend for the entire period under investigation.
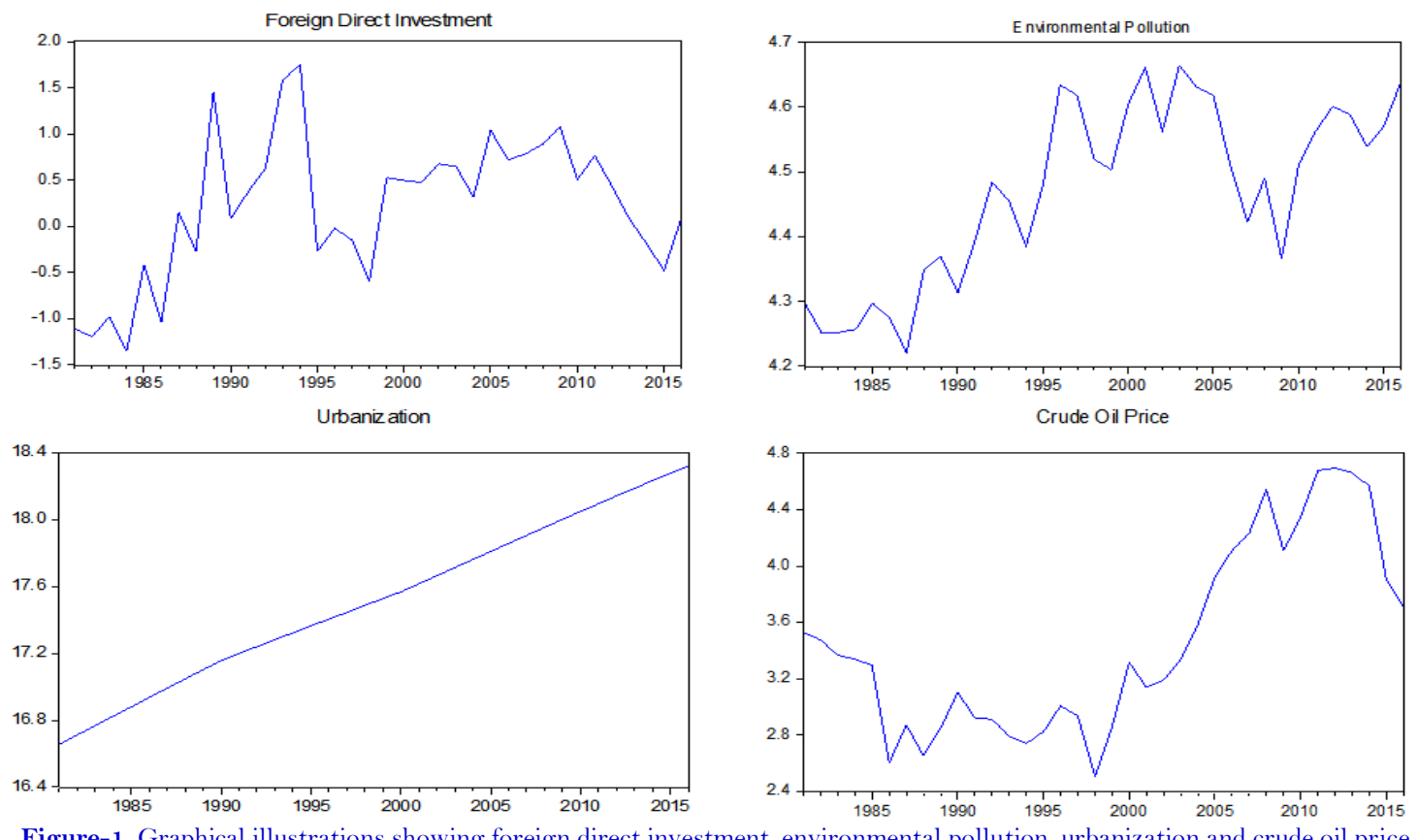

Figure-1. Graphical illustrations showing foreign direct investment, environmental pollution, urbanization and crude oil price in Nigeria. 


\subsection{Descriptive Analysis}

The descriptive and correlation analyses are reported in Table 2. From the side of the descriptive analysis, the result shows the mean, median, maximum and minimum values, standard deviation, kurtosis and skewness, JarqueBera value and its probability values. The standard deviation values for all the variables indicates that these variables are distributed far below their mean and median values on a comparative basis. Environmental pollution, foreign direct investment and urbanization are negatively skewed are indicated by the skewness values whereas crude oil price is positively skewed. All the variables are normally distributed within the study period of 1981 to 2016 as shown by the insignificant probability values for all the series. From the correlation analysis outcome all the variables are positively correlated with the dependent variable. Meaning that increase in any of the independent variable will cause increase in environmental pollution and more importantly, all the correlation coefficients are within the range of $0.37-080$ and this implies that there is no problem of multicollinearity among the series (Pordan, 2013).

Table-2. Descriptive and correlation analyses results

\begin{tabular}{c|c|c|c|c}
\hline Tests \& Data & $\ln \mathbf{E V}_{\mathbf{t}}$ & $\ln \mathbf{F I}_{\mathbf{t}}$ & $\ln \mathbf{U B}_{\mathbf{t}}$ & $\ln \mathbf{O P}_{\mathbf{t}}$ \\
\hline Mean & 4.469281 & 0.207103 & 17.51387 & 3.463009 \\
\hline Median & 4.497016 & 0.344786 & 17.50663 & 3.326793 \\
\hline Maximum & 4.664599 & 1.756279 & 18.32120 & 4.695468 \\
\hline Minimum & 4.220257 & -1.357039 & 16.65477 & 2.507972 \\
\hline Std. Dev. & 0.137867 & 0.777723 & 0.489590 & 0.670732 \\
\hline Skewness & -0.304505 & -0.201798 & -0.043259 & 0.538413 \\
\hline Kurtosis & 1.775976 & 2.544820 & 1.886405 & 2.027327 \\
\hline Jarque-Bera & 2.803692 & 0.555118 & 1.871368 & 3.158471 \\
\hline Probability & 0.246142 & 0.757631 & 0.392318 & 0.206133 \\
\hline Observations $^{\text {Ob }}$ & 36 & 36 & 36 & 36 \\
\hline $\ln \mathrm{FI}_{\mathrm{t}}$ & 1.0000 & & & \\
\hline $\ln \mathrm{UB}_{\mathrm{t}}$ & 0.3735 & 1.0000 & & \\
\hline $\ln \mathrm{OP}_{\mathrm{t}}$ & 0.3047 & 0.1291 & 0.6984 & 1.0000 \\
\hline
\end{tabular}

\subsection{Unit Root Tests Results}

To make decision with regards to the most appropriate test to conduct for the variables interest study, the time series data need to examine for their stationarity properties (Ali et al., 2017) even though the application of ARDL method does required formal unit root test for the variables but the test is performed just to be sure that none of the series is stationary at second difference i.e. I (2). Therefore, for the purpose of the current study, the variables' stationary properties are inspected using Augmented (Dickey \& Fuller, 1981) and Kwiatkowski, Phillips, Schmidt, and Shin (1992) unit roots and their results are reported in Table 3. The unit root test results using the ADF and KPSS unit root tests revealed a different result, the ADF results indicates that foreign direct investment and urbanization are stationary at level and these variables are said to be integrated of order o or more formally as I (o). But environmental pollution and crude oil price were not stationary at level but became stationary after first differencing and are said to be integrated of order 1 which is I (1). The results from KPSS unit root test revealed that all the series were stationary at level with exception of urbanization which is stationary at first difference. Therefore, the two results from ADF and KPSS unit root tests indicates a mixture of order of integration among the series and this is the perfect combination for the application of ARDL approach and we proceed to the test for cointegration. 
Table-3. ADF and KPSS unit root tests results.

\begin{tabular}{|c|c|c|c|c|}
\hline \multirow[b]{2}{*}{ Variables } & \multicolumn{2}{|c|}{ ADF } & \multicolumn{2}{|c|}{ KPSS } \\
\hline & Constant & Constant \&Trend & Constant & Constant \&Trend \\
\hline $\ln \mathrm{EV}_{\mathrm{t}}$ & $\begin{array}{l}-1.6627 \\
(0.4408)\end{array}$ & $\begin{array}{l}-2.5370 \\
(0.3096)\end{array}$ & $\begin{array}{c}0.2990 \\
(0.7390)^{* * * *}\end{array}$ & $\begin{array}{c}0.1058 \\
(0.2160)^{* * * *}\end{array}$ \\
\hline $\ln \mathrm{FI}_{\mathrm{t}}$ & $\begin{array}{c}-3.2257 \\
(0.0268)^{* * *}\end{array}$ & $\begin{array}{c}-3.2302 \\
(0.0952)^{*}\end{array}$ & $\begin{array}{c}0.2522 \\
(0.7390)^{* * * *}\end{array}$ & $\begin{array}{c}0.1170 \\
(0.2160)^{* * * *}\end{array}$ \\
\hline $\ln \mathrm{UB}_{\mathrm{t}}$ & $\begin{array}{l}-0.2781 \\
(0.9180)\end{array}$ & $\begin{array}{c}-6.4161 \\
(0.0001)^{* * * *}\end{array}$ & $\begin{array}{c}5.9060 \\
(0.7390) \\
\end{array}$ & $\begin{array}{c}0.2551 \\
(0.2160) \\
\end{array}$ \\
\hline $\operatorname{lnOP} \mathrm{P}_{\mathrm{t}}$ & $\begin{array}{l}-1.1556 \\
(0.6823) \\
\end{array}$ & $\begin{array}{l}-2.0914 \\
(0.5324) \\
\end{array}$ & $\begin{array}{c}0.4052 \\
(0.7390)^{* * * *} \\
\end{array}$ & $\begin{array}{c}0.1124 \\
(0.2160)^{* * * *} \\
\end{array}$ \\
\hline$\Delta \ln \mathrm{EV}_{\mathrm{t}}$ & $\begin{array}{c}-6.3821 \\
(0.0000)^{* * * *}\end{array}$ & $\begin{array}{c}-6.2936 \\
(0.0000)^{* * * *}\end{array}$ & $\begin{array}{c}0.0455 \\
(0.7390)^{* * * *}\end{array}$ & $\begin{array}{c}0.0452 \\
(0.2160)^{* * * *}\end{array}$ \\
\hline$\Delta \ln \mathrm{FI}_{\mathrm{t}}$ & $\begin{array}{c}-9.1189 \\
(0.0000)^{* * * *} \\
\end{array}$ & $\begin{array}{c}-9.2643 \\
(0.0000)^{* * * *} \\
\end{array}$ & $\begin{array}{c}0.1280 \\
(0.7390)^{* * * *} \\
\end{array}$ & $\begin{array}{c}0.0438 \\
(0.2160)^{\text {***** }} \\
\end{array}$ \\
\hline$\Delta \ln \mathrm{UB}_{\mathrm{t}}$ & $\begin{array}{c}-6.6987 \\
(0.0000)^{* * * *}\end{array}$ & $\begin{array}{c}-6.2002 \\
(0.0002)^{* * * *}\end{array}$ & $\begin{array}{c}0.3159 \\
(0.7390)^{* * * *}\end{array}$ & $\begin{array}{c}0.1918 \\
(0.2160)^{* * * *}\end{array}$ \\
\hline$\Delta \ln \mathrm{OP}_{\mathrm{t}}$ & $\begin{array}{c}-5.6082 \\
(0.0000)^{* * * *}\end{array}$ & $\begin{array}{c}-5.5274 \\
(0.0004)^{* * *}\end{array}$ & $\begin{array}{c}0.1665 \\
(0.7390)^{* * * *}\end{array}$ & $\begin{array}{c}0.1424 \\
(0.2160)^{* * * *}\end{array}$ \\
\hline
\end{tabular}

After the test for the presence of unit root in the variables as presented in the Table 3 above gave the way for the test of the possible existence of cointegration relationship among the series and the result is reported in Table 4 below. The calculate F-statistic value of 5.9142 is greater than the lower bound and the upper bound values at $1 \%$, $5 \%$ and $10 \%$ levels of significance respectively and at this point we strongly reject the null hypothesis that says there is no cointegration relationship among the series and accept the alternative hypothesis that says there is cointegration relationship among the variables. Therefore, the explain and the explanatory variables are moving together in the long-run.

Table-4. Cointegration test result.

\begin{tabular}{|c|c|c|c|}
\hline Model Specification & Period & Optimal lag length & F-statistic \\
\hline$F_{E V}\left[\ln E V_{t} \mid \ln F I_{t}, \ln U B_{t}, \ln O P_{t}\right]$ & $1983-2016$ & $\operatorname{ARDL}(1, \mathrm{O}, \mathrm{O}, 2)$ & $5.9142^{* * *}$ \\
\hline Critical value bounds & $10 \%$ & $5 \%$ & $1 \%$ \\
\hline Io Bound $(\mathrm{K}=3)$ & 2.72 & 3.23 & 4.29 \\
\hline I 1 Bound $(K=3)$ & 3.77 & 4.35 & 5.61 \\
\hline
\end{tabular}

The strong existence of cointegration relationship among the variables gave the courage for the examination of long-run and short-run coefficients and the outcomes are reported in Table 5. The outcome catches the significant negative impact of foreign direct investment on environmental pollution in the long run period. Precisely, $1 \%$ increase in the inflow of foreign direct investment is correlated with $0.0607 \%$ decrease in the level of environmental pollution for the period under study and this shows that foreign direct investment helps in reducing environmental pollution for the period of 1981-2016 in Nigeria. This empirical finding is in line with the findings of Mahmood et al. (2019a) for Egypt.

Moreover, urbanization has significant positive impact on the environmental pollution in the long run period. This means that increase in the urban population by $1 \%$ is the same thing as increasing the level of environmental pollution by $0.4297 \%$ in the long-run period and this indicate that urbanization is among the drivers of environmental pollution in the country as the empirical finding corroborate the findings of Ahmad et al. (2013) for South Asian nations, Mahmood and Zamil (2019) for Saudi.

Furthermore, crude oil price appeared to be negative and significantly associated with environmental pollution at $1 \%$ level of significant in the long-run. Particularly, $1 \%$ rise in the price of crude oil will help in reducing environmental pollution in the country by $0.1836 \%$ in the long-run period. This implies that earnings from increase 
crude oil prices in the international oil market helps in maintaining the quality of the environment. This empirical finding contradicts the researcher's findings such as Mahmood et al. (2020) for Saudi Arabia and Agbanike et al. (2019) for Venezuela, Mahmood and Zamil (2019) for Saudi.

Satisfying the econometric requirements of being significant, negative and less than one in values of the ECT makes it possible for the existence of the short-run coefficients and the ECT value of -0.6491 implies that the speed of convergence to equilibrium position when there is an existence of short-run dynamic is at $65 \%$ per year in the country. The short run parameters for all the variables with exception crude oil price follow their long run counterparts.

Table-5. ARDL estimation for environmental pollution model.

\begin{tabular}{|c|c|c|c|c|}
\hline \multicolumn{4}{|c|}{ Model: $\ln E V_{t}=\varphi_{0}+\varphi_{1} \ln F I_{t}+\varphi_{2} \ln U B_{t}+\varphi_{3} \ln O P_{t}+\zeta_{t}$} & \\
\hline \multirow[t]{2}{*}{ Variables } & & Specification & & \\
\hline & Coefficients & Std. Error & t-Statistic & Prob. \\
\hline \multicolumn{5}{|c|}{ Long-run estimation } \\
\hline Constant & $-2.4106^{* *}$ & 1.0182 & -2.3675 & 0.0253 \\
\hline $\operatorname{lnFI} I_{t}$ & $-0.0607^{*}$ & 0.0296 & -2.0480 & 0.0504 \\
\hline $\operatorname{lnUB}_{t}$ & $0.4297^{* * * *}$ & 0.0649 & 6.6178 & 0.0000 \\
\hline $\operatorname{lnOP}_{\mathrm{t}}$ & $-0.1836^{* * * *}$ & 0.0429 & -4.2738 & 0.0002 \\
\hline \multicolumn{5}{|c|}{ Short-run estimation } \\
\hline $\operatorname{ECM}(-1)$ & $-0.6491^{* * * *}$ & 0.1440 & -4.5075 & 0.0001 \\
\hline$\Delta \operatorname{lnFI} I_{t}$ & $-0.0394^{* *}$ & 0.0179 & -2.1953 & 0.0369 \\
\hline$\Delta \ln \mathrm{UB}_{\mathrm{t}}$ & $0.2789^{* * * *}$ & 0.0675 & 4.1288 & 0.0003 \\
\hline$\Delta \ln \mathrm{OP}_{\mathrm{t}}$ & 0.0386 & 0.0433 & 0.8921 & 0.3802 \\
\hline$\Delta \operatorname{lnOP} \mathrm{t}_{\mathrm{t}-1}$ & $0.0997^{* *}$ & 0.0442 & 2.2531 & 0.0326 \\
\hline
\end{tabular}

After the estimation of the cointegration, long-run and short-run models followed the reliability checks in order to determine the strength of the estimated model and the result is offered in Table 6 . The outcome revealed that for all the tests, their null hypotheses cannot be rejected and this is a sign of a good model as the model has passed all the reliability tests. But one important thing with regard to the passing all the tests is the stability of the model. The stability test as suggested by Brown, Durbin, and Evans (1975) was implemented and the outcome showed that there is stability among the variables throughout the study periods and the outcome is illustrated in Figure 2.

Table-6. Reliability tests.

\begin{tabular}{c|c|c}
\hline Test statistics & F Version & LM version \\
\hline A: Serial correlation & $0.5710[0.5721]$ & $1.4853[0.4758]$ \\
\hline B: Heteroscedasticity & $0.2057[0.9720]$ & $1.4866[0.9604]$ \\
\hline C: Normality & $1.0827[0.5819]$ & Not applicable \\
\hline D: Functional Form & $1.6126[0.2154]$ & $1.2699[0.2154]$ \\
\hline CUSUM & Stable & \\
\hline CUSUMSQ & Stable & \\
\hline
\end{tabular}

Note: A: Breusch-Godfrey Serial Correlation LM test.

B: Based on Breusch-Pagan-Godfrey.

C: Based on Jarque-Bera test.

D: Ramsey RESET test using squares of fitted values. 

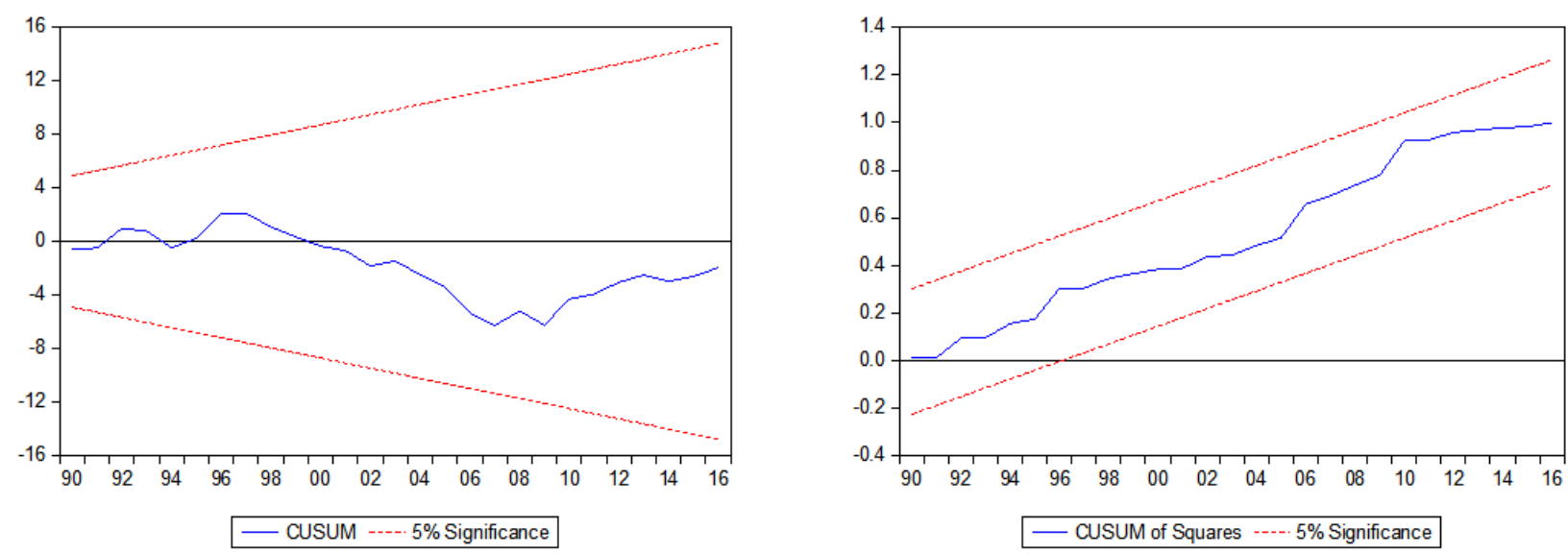

Figure-2. Plots of CUSUM and CUSUMSQ for the stability of the model.

The dynamic ordinary least squares (DOLS), fully modified ordinary least squares (FMOLS) and canonical cointegration regression (CCR) were employed because they are the perfect checks for the long-run ARDL coefficients and the results are depicted in Table 7. The from the three estimators confirms the existence of the long-run ARDL coefficients with exception of foreign direct investment which appears to be insignificant under the three estimators respectively.

Table-7. Estimated results for DOLS, FMOLS and CCR.

\begin{tabular}{|c|c|c|c|c|c|c|}
\hline DV = Env. Pollution. & \multicolumn{2}{|c|}{ DOLS } & \multicolumn{2}{|c|}{ FMOLS } & \multicolumn{2}{|c|}{ CCR } \\
\hline Regressors & Coefficients & SE & Coefficients & SE & Coefficients & SE \\
\hline Foreign D. Investment & $\begin{array}{c}-0.0431 \\
(-1.1461)\end{array}$ & 0.0376 & $\begin{array}{c}-0.0133 \\
(-0.5644)\end{array}$ & 0.0236 & $\begin{array}{c}-0.0250 \\
(-0.8309)\end{array}$ & 0.0301 \\
\hline Urbanization & $\begin{array}{l}0.3384^{* * * *} \\
(3.8563)\end{array}$ & 0.0877 & $\begin{array}{c}0.3416^{* * * *} \\
(6.1727)\end{array}$ & 0.0553 & $\begin{array}{l}0.3526^{* * * *} \\
(5.8927)\end{array}$ & 0.0598 \\
\hline Crude oil price & $\begin{array}{l}-0.1384^{* * *} \\
(-2.6802)\end{array}$ & 0.0516 & $\begin{array}{c}-0.1311^{* * * *} \\
(-3.6348)\end{array}$ & 0.0360 & $\begin{array}{c}-0.1348^{* * * *} \\
(-3.6924)\end{array}$ & 0.0365 \\
\hline Constant & $\begin{array}{l}-0.8056 \\
(-0.5301) \\
\end{array}$ & 1.5195 & $\begin{array}{l}-1.0556 \\
(-1.2008)\end{array}$ & 0.8791 & $\begin{array}{l}-1.2299 \\
(-1.2977) \\
\end{array}$ & 0.9477 \\
\hline $\mathrm{R}^{2} \&$ Adjusted $\mathrm{R}^{2}$ & $0.8530 \&$ & 7648 & $0.6338 \&$ & 5984 & $0.6221 \& 0.5855$ & \\
\hline
\end{tabular}

Note: () are the t-Statistics. DV = Dependent variable, DOLS = dynamic ordinary least squares; FMOLS = fully modify ordinary least square; Canonical Cointegration Regression; OLS = Ordinary Least Square; $\mathrm{SE}=$ Standard Error. ${ }^{* * * * * * *} *$ indicates significant at 1,5 and $10 \%$ levels of significance respectively.

\section{CONCLUSION AND RECOMMENDATIONS}

Nigeria has been through speedy urbanization in the past few years and revenue realized from oil exports is the important part of the country's sources of revenue since 80's. the current study examined the influence of urbanization and price of crude oil on the level of environmental pollution in Nigeria through the widely used ARDL approach for cointegration covering the period of 1981-2016. Our finding is able to catch positive and significant impact of urbanization on environmental pollution in the country. And it signifies that rapid and constant growing urbanization during the study sample period is held accountable for environmental degradation through the emission of $\mathrm{CO}_{2}$. But foreign direct investment and price of crude oil were found to be negatively sign with environmental pollution in the long run period and so the short run coefficient of foreign direct investment but the that of crude oil price was found to be positive and significant.

Therefore, based on our empirical findings, we recommend that for the country to maintain good environmental quality, the country must limit the process of urbanization to best level in order to reduce the associated environmental impacts and this does not mean complete shutting down of projects and activities that concentrate on urbanization but just to maintain a balance were the quality of the environment is not harm by the increasing urbanization. With the presence of efforts on development and urbanization, it is now a right for the 
Nigerian government to create an extended strategy and the with the continue focusing on crude oil exploration, as the rising price of crude oil has positive impact on the total revenue of the economy. Even though the crude oil earnings and urbanization may possess some welfare impacts through rising level of standard of living and consumption but their collective negative effects in terms of polluting the environment cannot be neglected in order to clear positive wellbeing from them.

Funding: This study received no specific financial support.

Competing Interests: The authors declare that they have no competing interests.

Acknowledgement: All authors contributed equally to the conception and design of the study.

\section{REFERENCES}

Acar, S. (2017). The course of natural resources: A development analysis in a comparative context. New York: Springer.

Agbanike, T. F., Nwani, C., Uwazie, U. I., Anochiwa, L. I., Onoja, T. G. C., \& Ogbonnaya, I. O. (2019). Oil price, energy consumption and carbon dioxide ( $\mathrm{CO} 2)$ emissions: Insight into sustainability challenges in Venezuela. Latin American Economic Review, 8(8), 1-26. Available at: https://doi.org/10.1186/s40503-019-0070-8.

Ahmad, N., Iqbal, A., \& Mahmood, H. (2013). CO2 Emission, population and industrial growth linkages in selected South Asian countries: A co-integration analysis. World Applied Sciences Journal, 21(4), 615-622.

Ahmad., M., Hengyi, H., Rahman, Z. U., Khan, Z. U., Khan, S., \& Khan, Z. (2018). Carbon emissions, energy use, gross domestic product and total population in China. Economics and Environment, 2(65), 32-44.

Ahmed, K., Shahbaz, M., Qasim, A., \& Long, W. (2015). The linkages between deforestation, energy and growth for environmental degradation in Pakistan. Ecological Indicators, 49, 95-103. Available at: https://doi.org/10.1016/j.ecolind.2014.09.040.

Al-mulali, U., \& Ozturk, I. (2015). The effect energy consumption, urbanization trade openness, industrial output, and the political stability on the environmental degradation in the MENA (Middle East and North Africa) region. Energy, 84(C), 382-389. Available at: 10.1016/j.energy.2015.03.004.

Ali, W., Abdullah, A., \& Azam, M. (2017). Re-visiting the environmental Kuznets curve hypothesis for Malaysia: fresh evidence from ARDL bounds testing approach. Renewable and Sustainable Energy Reviews, 77, 990-1000. Available at: https://doi.org/10.1016/j.rser.2016.11.236.

Alshehry, A. S., \& Belloumi, M. (2015). Energy consumption, carbon dioxide emissions and economic growth: The case of Saudi Arabia. Renewable and Sustainable Energy Reviews, 41, 237-247. Available at: https://doi.org/10.1016/j.rser.2014.08.004.

Balcilar, M., Ozdemir, Z. A., Ozdemir, H., \& Shahbaz, M. (2018). Carbon dioxide emissions, energy consumption and economic growth: The historical decomposition evidence from G-7 countries. Retrieved from: https://ideas.repec.org/p/emu/wpaper/15-41.pdf.html.

Begum, R. A., Sohag, K., Abdullah, S. M. S., \& Jaafar, M. (2015). CO2 emissions, energy consumption, economic and population growth in Malaysia. Renewable and Sustainable Energy Reviews, 41, 594-601. Available at: https://doi.org/10.1016/j.rser.2014.07.205.

Behera, S. M., \& Dash, D. P. (2017). The effect of urbanization, energy consumption, and foreign direct investment on the carbon dioxide emission in the SSEA (South and Southeast Asian) region. Renewable and Sustainable Energy Reviews, $70(\mathrm{C}), 96-$ 106. Available at: https://doi.org/10.1016/j.rser.2016.11.201.

Brown, R. L., Durbin, J., \& Evans, J. M. (1975). Techniques for testing the constancy of regression relationships over time. Journal of the Royal Statistical Society: Series B (Methodological), 37(2), 149-163.

Dickey, D. A., \& Fuller, W. A. (1981). Likelihood ratio statistics for autoregressive time series with a unit root. Econometrica, 49(4), 1057-1072. 
Farhani, S., \& Ozturk, I. (2015). Causal relationship between $\mathrm{CO} 2$ emissions, real GDP, energy consumption, financial development, trade openness, and urbanization in Tunisia. Environmental Science and Pollution Research, 22(20), 1566315676. Available at: https://doi.org/10.1007/s11356-015-4767-1.

Ikporukpo, C. O. (2018). Urbanization and the environment: The debate and evidence from two new cities in Nigeria. Journal of Geography and Regional Planning, 11(5), 61-79. Available at: https://doi.org/10.5897/jgrp2018.0681.

Imamoglu, H. (2019). The role of financial sector in energy demand and climate changes: evidence from the developed and developing countries. Environmental Science and Pollution Research, 26(22), 22794-22811. Available at: https://doi.org/10.1007/s1 1356-019-05499-y.

Isik, C., Dogru, T., \& Turk, E. S. (2018). A nexus of linear and non-linear relationships between tourism demand, renewable energy consumption, and economic growth: Theory and evidence. International Journal of Tourism Research, 20(1), 3849. Available at: https://doi.org/10.1002/jtr.2151.

Kasman, A., \& Duman, Y. S. (2015). CO2 emissions, economic growth, energy consumption, trade and urbanization in new EU member and candidate countries: a panel data analysis. Economic Modelling, 44, 97-103. Available at: https://doi.org/10.1016/j.econmod.2014.10.022.

Khobai, H., \& Le Roux, P. (2017). The relationship between energy consumption, economic growth and carbon dioxide emission: The case of South Africa. International Journal of Energy Economics and Policy, 7(3), 102-109. Available at: https://doi.org/10.1504/ijse.2018.10009728.

Khraief, N., Shahbaz, M., Mallick, H., \& Loganathan, N. (2018). Estimation of electricity demand function for Algeria: Revisit of time series analysis. Renewable and Sustainable Energy Reviews, 82, 4221-4234. Available at: https://doi.org/10.1504/ijse.2018.10009728.

Kwiatkowski, D., Phillips, P. C., Schmidt, P., \& Shin, Y. (1992). Testing the null hypothesis of stationarity against the alternative of a unit root. Journal of Econometrics, 54(1-3), 159-178. Available at: https://doi.org/10.1111/1467-9892.00213.

Maalel, N., \& Mahmood, H. (2018). Oil-abundance and macroeconomic performance in the GCC countries. International Journal of Energy Economics and Policy, 8(2), 182-187. Available at: https://doi.org/10.1016/j.rser.2016.1 1.106.

Mahalik, M. K., Babu, M. S., Loganathan, N., \& Shahbaz, M. (2017). Does financial development intensify energy consumption in Saudi Arabia? Renewable and Sustainable Energy Reviews, 75, 1022-1034. Available at: https://doi.org/10.1016/j.rser.2016.11.081.

Mahmood, H., \& Alkhateeb, T. T. Y. (2017). Trade and environment nexus in Saudi Arabia: An environmental Kuznets curve hypothesis. International Journal of Energy Economics and Policy, 7(5), 291-295.

Mahmood, H., Alkhateeb, T. T. Y., Al-Qahtani, M. M. Z., Allam, Z., Ahmad, N., \& Furqan, M. (2020). Urbanization, oil price and pollution in Saudi Arabia. International Journal of Energy Economics and Policy, $10(2)$, 477-482. Available at: https://doi.org/10.32479/ijeep.8914.

Mahmood, H., Furqan, M., Alkhateeb, T. T. Y., \& Fawaz, M. M. (2019a). Testing the environmental Kuznets curve in Egypt: Role of foreign investment and trade. International Journal of Energy Economics and Policy, 9(2), 225-228.

Mahmood, H., \& Zamil, A. M. (2019). Oil price and slumps effects on personal consumption in Saudi Arabia. International Journal of Energy Economics and Policy, 9(4), 12-15.

Maji, I. K. (2015). The link between trade openness and deforestation for environmental quality in Nigeria. Geo Journal, 82(1), 131-138. Available at: https://doi.org/10.1007/s10708-015-9678-7.

Musa, K. S., Maijama'a, R., Mohammed, N., \& Usman, A. (2020). Crude oil price and exchangerate nexus: An ARDL bound approach. Open Access Library Journal, 7(e6072), 1-18.

Musa, K. S., Maijama'a, R., Shaibu, H. U., \& Muhammad, A. (2019). Crude oil price and exchange rate on economic growth: ARDL approach. Open Access Library Journal, 6(e5930), 1-16.

Musa., K. S., Maijama'a, R., Mohammed, N., \& Adamu, Y. (2020). Assessing the key drivers of energy demand in Nigeria: Application of ARDL approach. Global Scientific Journals, 8(6), 19-40.

Newman, P. (2006). The environmental impact of cities. Environment and Urbanization, 18(2), 275-295. 
Nwani, C. (2017). Causal relationship between crude oil price, energy consumption and carbon dioxide emissions in Ecuador. OPEC Energy Review, 41(3), 201-225. Available at: https://doi.org/10.1111/opec.12102.

Ohwo, O., \& Abotutu, A. (2015). Environmental impact of urbanization in Nigeria. British Journal of Applied Science and Technology, 9(3), 212-221.

Olusanya, S. O. (2012). Longrun relationship between energy consumption and economic growth: Evidence from Nigeria. Journal of Humanities and Social Sciences, 3(3), 40-51. Available at: https://doi.org/10.9790/0837-0334051.

OPEC. (2020). Organization of oil exporting countries crude oil prices 1960-2020. Retrieved from: https://www.statista.com/statistics/262858/change-in-opec-crude-oil-prices-since/1960/.

Pesaran, M. H., Shin, Y., \& Smith, R. J. (2001). Bounds testing approaches to the analysis of level relationships. Journal of Applied Econometrics, 16(3), 289-326. Available at: https://doi.org/10.1002/jae.616.

Pordan, I. (2013). The effects of whether on stock returns: A comparison between emerging and developed markets. Hamburg, Germany: Anchor Academic Publishing.

Rafindadi, A. A. (2016). Does the need for economic growth influence energy consumption and $\mathrm{CO} 2$ emissions in Nigeria? Evidence from the innovation accounting test. Renewable and Sustainable Energy Reviews, 62, 1209-1225. Available at: https://doi.org/10.1016/j.rser.2016.05.028.

Saboori, B., Al-Mulali, U., Bin Baba, M., \& Mohammed, A. H. (2016). Oil-induced environmental Kuznets curve in organization of petroleum exporting countries (OPEC). International Journal of Green Energy, 13(4), 408-416. Available at: https://doi.org/10.1080/15435075.2014.961468.

Shahbaz, M., Hye, Q. M. A., Tiwari, A. K., \& Leitão, N. C. (2013). Economic growth, energy consumption, financial development, international trade and $\mathrm{CO} 2$ emissions in Indonesia. Renewable and Sustainable Energy Reviews, 25, 109-121. Available at: https://doi.org/10.1080/15435075.2014.961468.

Sulaiman, C., \& Abdul-Rahim, A. (2018). Population growth and $\mathrm{CO} 2$ emission in Nigeria: a recursive ARDL approach. Sage Open, 8(2), 2158244018765916 . Available at: https://doi.org/10.1177/2158244018765916.

WDI. (2020). World bank's world development indicators. Retrieved from: https://data.worldbank.org/indicator.

Zamil, A., Furqan, M., \& Mahmood, H. (2019). Trade openness and $\mathrm{CO} 2$ emissions nexus in Oman. Entrepreneurship and Sustainability Issues, 7(2), 1319-1329. Available at: https://doi.org/10.9770/jesi.2019.7.2(36).

Views and opinions expressed in this article are the views and opinions of the author(s), Asian Journal of Economic Modelling shall not be responsible or answerable for any loss, damage or liability etc. caused in relation to/arising out of the use of the content. 